\title{
Harvesting reflective knowledge exchange for inbound open innovation in complex collaborative networks: an empirical verification in Europe
}

\author{
Armando Papa, Roberto Chierici, Luca Vincenzo Ballestra, Dirk Meissner and \\ Mehmet A. Orhan
}

\begin{abstract}
Purpose - This study aims to investigate the effects of open innovation (OI) and big data analytics (BDA) on reflective knowledge exchange (RKE) within the context of complex collaborative networks. Specifically, it considers the relationships between sourcing knowledge from an external environment, transferring knowledge to an external environment and adopting solutions that are useful to appropriate returns from innovation.
\end{abstract}

Design/methodology/approach - This study analyzes the connection between the number of patent applications and the amount of OI, as well as the association between the number of patent applications and the use of BDA. Data from firms in the 27 European Union countries were retrieved from the Eurostat database for the period 2014-2019 and were investigated using an ordinary least squares regression analysis.

Findings - Because of its twofold lens based on both knowledge management and OI, this study sheds light on OI collaboration modes and highlights the crucial role they could play in innovation. In particular, the results suggest that OI collaboration modes have a strong effect on innovation performance, stimulating the search for RKE.

Originality/value - This study furthers a deeper understanding of RKE, which is shown to be an important mechanism that incentivizes firms to increase their efforts in the innovation process. Further, RKE supports firms in taking full advantage of the innovative knowledge they generate within their interorganizational network.

Keywords Open innovation, Knowledge dissemination, Big data analytics, Complex collaborative networks, Patent applications, Reflective knowledge exchange

Paper type Research paper

\section{Introduction}

In a complex business environment where markets are affected by several transformations, firms are often required to address intensified competitive pressure without delay to survive, while facing an international scenario that has become increasingly dynamic and turbulent (Ferraris et al., 2016). The emergent interdependence of the world's economies, cultures and populations, the rapid shift of many industries and borders, the growth of technology intensity and increased competition require firms to adopt innovative solutions to handle the constant change (Weber and Tarba, 2014).

To respond to the challenges presented by these new elements, firms need to continuously upgrade and improve their learning processes and establish new knowledge
(Information about the authors can be found at the end of this article.)

Received 24 April 2020

Revised 14 July 2020

Accepted 5 August 2020

(C) Armando Papa Roberto Chierici, Luca Vincenzo Ballestra, Dirk Meissner and

Mehmet A. Orhan. Published by Emerald Publishing Limited. This article is published under the Creative Commons Attribution (CC BY 4.0) licence. Anyone may reproduce, distribute, translate and create derivative works of this article (for both commercial and non-commercial purposes), subject to full attribution to the original publication and authors. The full terms of this licence may be seen at http:// creativecommons.org/ licences/by/4.0/legalcode

The authors are appreciative of Dirk Meissner's contribution which is based on the study's funding by the Basic Research Program of the National

Research University Higher School of Economics (HSE) and by the Russian Academic Excellence Project "5-100." 
(Del Giudice and Maggioni, 2014). To accomplish this in a dynamic environment, firms have to continuously renew and redefine their resources and competencies (Nonaka and Takeuchi, 1995) and reconfigure existing knowledge assets (Jiménez-Jiménez et al., 2014) to acquire sustainable competitiveness. From this perspective, innovation - which can be defined as a firms' capacity to produce novel product or services continuously (Galunic and Rodan, 1998) - plays a pivotal role, owing to firms' capacity to develop new knowledge. Input from different internal functions represents the key elements for generating new opportunities to innovate, even though a growing number of innovation processes rely on opportunities identified, developed and harnessed in collaboration with outside sources (Terwiesch and $\mathrm{Xu}, 2008$ ).

This phenomenon, also known as open innovation (OI) (Chesbrough, 2003; Gassmann, 2006), represents a new paradigm in innovation management (Chesbrough and Crowther, 2006). It originated in the high-tech industry and has recently increased dramatically in forms from different sectors and industries (Bughin et al., 2008). Ol is a complex issue that has been investigated by different research streams (Gassmann, 2006). The first line of research investigates technology transactions, focusing on inward technology transfer and R\&D alliances to explain why firms have to establish internal organizational capability (Lichtenthaler and Lichtenthaler, 2009). Another stream of research moves on from Von Hippel's $(1978,1986)$ seminal works regarding the role of users in the generation of innovations; it mainly investigates firms' relationships with customers as external sources of new knowledge and ideas in the OI process (Bogers et al., 2010). A further line of research studies innovation markets, in particular, it analyzes how firms can be supported in developing Ol modes (Chesbrough, 2007). A last line of research investigates the role of business models in the Ol framework while focusing on how firms can exploit knowledge and appropriate the innovation it generates (van der Meer, 2007). OI refers to the use of both inflowing and outflowing knowledge to support and enhance the innovation process. It represents a strategic management tool for firms to cope with constant change and to resolve issues relying only on internal R\&D for generating innovation (Lee et al., 2015). It also provides a concrete solution for firms that need to develop partnerships that are useful for establishing sustainable innovation (Kauppila, 2010).

In the OI scenario, firms are enhancing their competitiveness by promoting collaborative approaches, both inside the organization (among employees) and outside (among shareholders) (Battistella et al., 2013). Big data, known as huge amounts of structured and unstructured data, accessible in real time (O'Leary, 2013) have recently been found to significantly support Ol, as big data offer a concrete contribution to setting up communities and contests where firms can disseminate new ideas and solutions regarding their OI strategies. Nevertheless, to experience the full advantages of big data, firms must be able to analyze the extensive information comprised in big data by themselves. Only firms that are capable of managing large amounts of data generated by different sources in real time and who adopt big data analytics (BDA) have the opportunity to fully exploit big data for gaining better insights, effectively supporting the decision-making process and developing innovation (Chen et al., 2012; Del Vecchio et al., 2018).

Although previous studies have highlighted the growing penetration of $\mathrm{Ol}$ and management literature has suggested that strategic alliances between firms could lead to significant benefits (Lee et al., 2010), firms are struggling to understand the role of appropriability in enabling $\mathrm{OI}$ practices. In fact, the adoption of an openness approach requires managers to reassess the processes of value creation and value capture; more specifically, the mechanism by which firms can appropriate the returns on the inventions originated from OI processes should be better understood (West et al., 2014). As innovation relying on knowledge exchange and collaborative networks turned out to play a crucial role in managing complex knowledge (Singh, 2005), firms are often interested in establishing relationships and partnerships with external actors (Shi et al., 2019). Some literature suggests that establishing collaborations with external entities could represent a strategic 
driver that may support firms in obtaining feedback and in developing their own knowledge and skills with outside expertise, thus assimilating new advanced technical and scientific information and seeding for future developments (Chesbrough, 2003; Kafouros and Forsans, 2012). Even if knowledge transfer is considered to be one of the most promising paths to strengthening firm competitiveness, previous studies suggest that interorganizational collaborations and alliances could lead to jarring results (Inkpen, 2008). However, knowledge exchange is a sophisticated process that requires firms to manage several challenging tasks, ranging from developing routines that support interaction and collaboration within the collaborative network to collective learning and sharing ideas and solutions with partners. The positive impact of external collaboration and networking may be coupled with negative side effects, not only because these collaborative processes could fail but also because these associations expose firms to competitive loss, as strategic knowledge could be dispersed outside of firms (Hurmelinna-Laukkanen, 2011). In fact, when engaged in collaborative networks, firms may have to manage some criticalities such as the dispersion of critical knowledge (Khanna et al., 1998) and conflicts regarding the division of returns derived from shared information, experience and knowledge.

The current state of OI research calls for extended research (Chesbrough et al., 2014); therefore, the present study moves from these considerations and proposes a model that - by examining data from firms located in the 27 European Union (EU) countries - investigates the relationships among reflective knowledge exchange (RKE), the extent of $\mathrm{OI}$, the amount of BDA and the number of applications for patents. Even though a plethora of studies support the idea that effective interorganizational networks that implement OI practices and BDA enjoy the benefits of idea generation, innovativeness and intellectual property outcomes, the empirical evidence on a larger scale is still lacking (Clark and Stoddard, 1996; Del Giudice and Maggioni, 2014; Jenssen and Nybakk, 2013). The current study contributes to the existing literature in several areas. Existing literature on the Ol process shows that $\mathrm{Ol}$ is about the use of inflows and outflows of knowledge to stimulate firms to generate innovation and succeed. This study aims to understand whether collaborations with other firms to generate innovation should be enacted in a protected environment. More specifically, the main aim of the study is to provide a better understanding of the determinants of participation in both outside-in and inside-out OI projects. Further, the research contributes to the OI literature by proposing a quantitative investigation on whether firms cooperating with other partners to generate new knowledge require protection for their innovation.

As a second contribution, the present study sheds light on the role of BDA in the OI process by investigating the connection between the number of patent applications and the use of $\mathrm{BDA}$ in the process of knowledge creation, exchange and dissemination.

The remainder of the study is structured as follows: Section 2 presents the literature review and develops the research hypotheses. Sections 3 and 4 describe the methodology and the main findings of the research, respectively, while a critical discussion of the results is presented in Section 5. This section also points out the implications and the limitations of the study and presents the conclusions drawn.

\section{Literature review and hypotheses development}

\subsection{Open innovation and patent applications in complex knowledge relationships}

Because innovation represents one of the most important sources of competitive advantage, several studies have attempted to identify its main drivers (Jiménez-Jiménez et al., 2014). In short, firm innovation is rooted in both social networks, referring to relationships with their stakeholders, and knowledge networks, which are created through collaborative knowledge associations (Guan and Liu, 2016).

Assuming a within-firm perspective, organizations have long strived to understand how they can support employees when they collaborate in a distributed team. As globalization has 
encouraged firms to establish subsidiaries across the world, employees find themselves working in an environment with few space, time and organizational boundaries, to develop new knowledge and to pursue common aims (Majchrzak et al., 2005; Malhotra and Majchrzak, 2004). RKE is set not only within and between different business organizations; managers have also attempted to develop alliances and collaborations to support knowledge sharing with several stakeholders, such as suppliers (Lager et al., 2014), partners (de Zubielqui et al., 2019) and universities (Meng et al., 2019).

Knowledge has a pivotal role in the value creation process and internal R\&D is no longer adequate to compete in a highly demanding environment. Therefore, the OI approach has been introduced to support firms in understanding how they can create knowledge and which pathways they can follow to achieve a competitive advantage. Since the seminal study of Chesbrough (2003), the Ol theory asserts that firms should exploit "external ideas as well as internal ideas, and internal and external paths to market [...]" (Chesbrough, 2003 , p. 24), recognizing that knowledge resources can be derived both internally and externally. Inbound $\mathrm{OI}$ is described as an outside-in process and involves the practice of leveraging knowledge and technologies retrieved from outside the firm. This practice requires firms to establish interorganizational relationships with external actors to exploit their knowledge and competencies (Bianchi et al., 2011; Chesbrough, 2007). In addition to the collaborative outside-in OI, firms can obtain an additional advantage from another practice, so-called outbound $\mathrm{OI}$, which is an inside-out process that allows firms to commercially exploit their unused knowledge by transferring intellectual property to external actors (Chesbrough, 2007, 2003).

Generally speaking, the co-existence of these two different OI perspectives paves the way for further debate on how firms can effectively manage different knowledge flows to improve competitiveness. In fact, many firms have decided to simultaneously adopt both the inbound and the outbound approaches (van de Vrande et al., 2009). Further, because of the increase in international competition, firms cannot rely on one of these two approaches alone. Considering that the stimulation of co-operations and networks has become very popular, firms should establish relationships with several external stakeholders to access and leverage inputs from the external environment that can be useful in generating new knowledge (Scuotto et al., 2017). However, while staying on top of the competition and constantly developing new knowledge and innovation is a highly resource-demanding task, imperfect appropriability has been identified as a factor that induces both partners in and outsiders to the cooperative agreement to free ride on firms' knowledge (Greenlee and Cassiman, 1999; Kesteloot and Veugelers, 1995). Specifically, firms are continuously seeking solutions such as trademarks, copyrights and patents that could contribute toward reducing the involuntary dispersion of knowledge and effectively support them in claiming ownership of inventions by their R\&D departments. In fact, it is especially difficult to obtain value solely from leveraging knowledge in highly competitive markets. Therefore, many firms find setting up collaborative networks in which they can exchange knowledge and technology by selling or revealing them particularly attractive (Lichtenthaler, 2009); accordingly, they tend to exploit the outbound Ol opportunities.

It is therefore important to investigate the relationships between sourcing knowledge from the external environment, transferring knowledge to the external environment and the firms' choices involving appropriate returns from innovation.

Previous studies have also documented a direct association between OI practices and intellectual property outputs, including patents. For instance, Veugelers et al. (2010) argued that early access to $\mathrm{OI}$ and relevant technologies increased commitment to technology investment strategies, which could predict scientific organizational breakthroughs and intellectual property output. Furthermore, the organizations that promote Ol practices by transforming intellectual property strategies as enablers will further enjoy idea provocation, knowledge creation and knowledge distribution among relevant interorganizational 
collaborators (Alexy et al., 2009). In existing literature, the volume of OI is often operationalized and measured by the number of collective patent applications made by interorganizational networks. A relatively recent study comprising a network analysis of OI conducted by Yun et al. (2016) also indicated that the number of joint patents submitted by interorganizational alliances are heavily influenced by OI practices, which are shaped by the structure of organizational collaboration networks; the stronger the ties between the organizations, the more collaboratively they perform. Hence, we propose the following research hypothesis:

H1. The number of patent applications is associated with the amount of OI.

\subsection{Impact of big data analytics on patent applications}

During the past decade, both academics and practitioners have paid increasing attention to big data. This increase is motivated by the possible contribution of big data toward solving business challenges and generating innovation. In particular, BDA has come to play a crucial role for firms seeking to innovate, as it contributes toward reducing uncertainty. This is especially relevant to uncertainty rooted in the external environment, such as variations in consumer preferences and exogenous technological change (Buckley and Carter, 2002). When using BDA, firms have to process both structured and unstructured data on customers and markets (Akter and Wamba, 2016) to acquire meaningful insights that can be used to generate new knowledge and promote effective decision-making. However, dealing with big data is a challenging task that involves large amounts of different kinds of information, such as transaction data from both online and offline stores, clickstream data from social media and video and voice data (Akter et al., 2016). Hence, to fully exploit the superior opportunities offered by big data, firms have to navigate three main challenges:

1. choosing the data sources and which information to use;

2. developing the capabilities to analyze data and manage analytics; and

3. using the insights gained from big data to transform the firms' operations (Del Vecchio et al., 2018; McGuire et al., 2013).

In an Ol scenario, firms have to adopt a critical attitude to address these three issues. Concerning the source and selection of data, firms need to consider that the value derived from big data depends on the quality of the different processes of data collection and analysis. To exploit the full potential of BDA and to take advantage of its unique characteristics, firms cannot adopt traditional methods of data selection; they need to develop ad hoc human and technical capabilities (Davenport et al., 2012). Firms also need to be aware that returns on investment in big data occur only if employees are trained to understand, use and include the related analytics in their decision-making processes (Shah et al., 2012). Furthermore, the combination of Ol and the availability of big data offer new challenges, as it offers the opportunity to identify innovation that could represent solutions to unsolved problems. Finally, BDA and its associated insights represent a powerful source of innovation that can contribute toward completely redesigning firm processes and identifying new business opportunities. From this perspective, it is also fundamental for firms to use BDA to develop innovation regarding their knowledge creation processes through a clearer understanding of the business environment (Davenport et al., 2012).

Managing relevant knowledge gained from BDA is complex; it requires firms to implement a structured approach to knowledge management (KM) (Ferraris et al., 2018). Previous studies have suggested that for BDA to contribute toward generating new knowledge, firms need to develop the capabilities of gaining information from external sources, understanding the external environment and generating innovative solutions through appropriate KM practices (De Dreu and West, 2001; Nguyen et al., 2015). Moreover, to 
make effective use of BDA, firms have to develop the skills for extracting significant information from a huge amount of heterogeneous data, exploit this information for making strategic and operational decisions and develop solutions for disseminating insights throughout the organization as well as to the partners in the collaborative networks they belong to. If correctly managed, BDA could foster internal knowledge creation, sharing of common knowledge or business intelligence and the development of human knowledge (Khan and Vorley, 2017). From a knowledge spillover perspective, firms' activities and innovative solutions could involuntarily generate dispersed knowledge to other firms. These firms that are operating in either the same industry or in a different sector could then take advantage of this knowledge to enhance their performance (Del Giudice et al., 2017). As BDA could result in a significant improvement in $\mathrm{KM}$, firms may want to protect the mechanism they adopt to effectively contribute to the decision-making process and improve business functions, as well as the knowledge obtained by adopting BDA (Gold et al., 2001; Malhotra and Majchrzak, 2004).

The ever-changing nature of knowledge creation, generation and distribution in organizations is affected by the introduction of new technologies and the capabilities of these new technologies. Technological capacity has been shown to be a crucial indicator of innovativeness, using patent applications as a predictor (Tong and Frame, 1994). Increasingly, firms are not only competing in the organizational resources they hold but also in knowledge creation. To do so, they use their existing resources by using predictive and prescriptive business analytics and converting big data into new, meaningful and actionable knowledge (Philip, 2018). These capabilities allow firms to not only excel in forecasting, production and quality control management but also provide access to novel information for improved decision-making to gain a competitive advantage. The association between innovation performance - measured by the number of patent applications - patent quality and technological investments and BDA has been a cumbersome issue, as the quantification of the amount of the big data used by organizations is challenging (Zhang et al., 2017). However, previous studies used a wide range of measures - including information on investments for implementing big data, the size of data analyzed and patents using BDA - to investigate these associations (Braganza et al., 2017). As the patents using big data have been previously highlighted in the literature examining innovative performance, we state the following research hypothesis:

H2. The number of patent applications is associated with the amount of BDA.

For convenience, the research steps performed in this study are summarized in Figure 1.

\section{Empirical analysis}

\subsection{Research context}

To test our hypotheses, we used an ordinary least squares (OLS) linear regression to empirically test the structural relationships of our conceptual model (Stock and Watson, 2003; Wooldridge, 2002). This methodology allows us to confirm or reject $H_{1}$ and $H_{2}$ by evaluating if the relationships between the dependent and the independent variables are statistically significant.

In our case, the use of a regression technique appears to be appropriate, as all the variables included in our analysis are perfectly measured, meaning that there is no latent (unobserved) factor to consider. In addition, it is worth noting that the OLS approach is widely used in practical applications - particularly in economics - to estimate the parameters of regression models (Hellwig, 1963; Kennedy, 1998; Wooldridge, 2002). The OLS method yields a direct and practical test to assess the significance of the regressors used, especially when it is used in conjunction with a robust standard error estimator (Darlington and Hayes, 2016; Stock and Watson, 2003; White, 1980; Wooldridge, 2002). 


\section{Setting the research design}

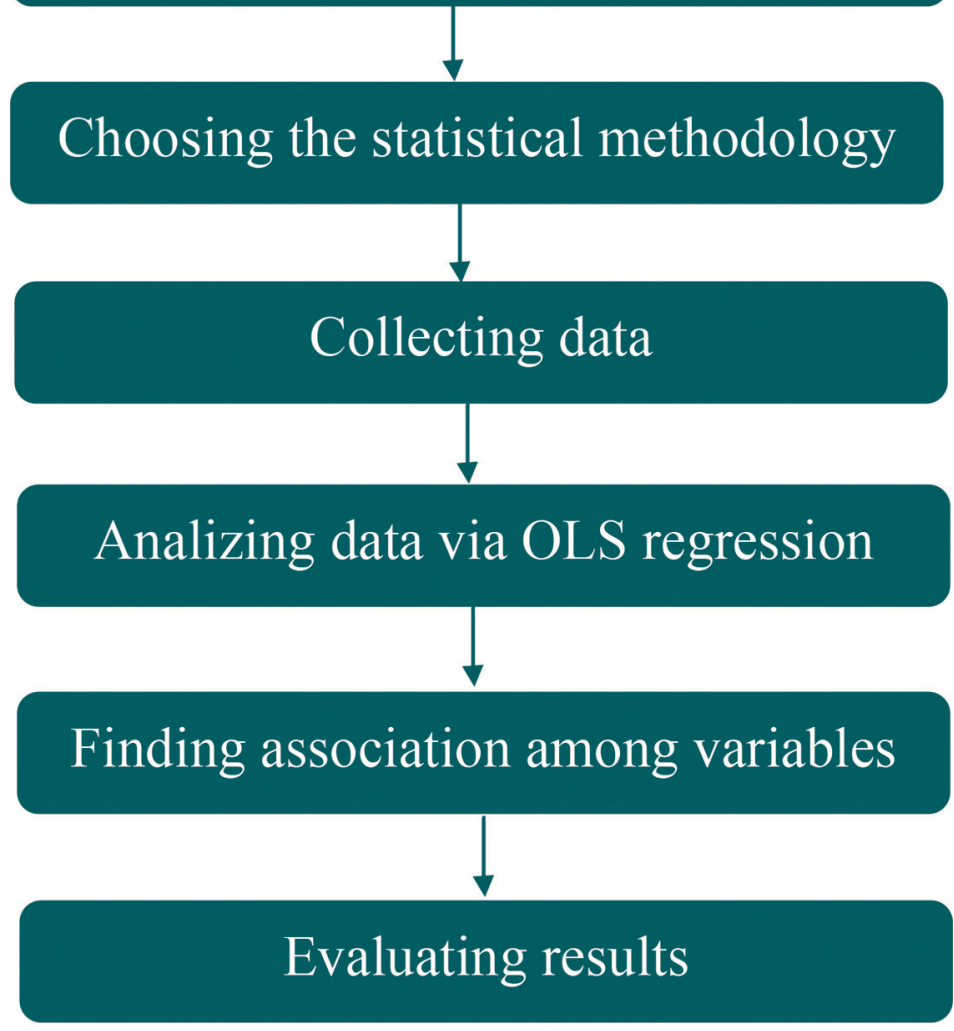

Source: Author's elaboration

As stated earlier, the regression technique is used to investigate the association between the number of patent applications and the amount of $\mathrm{OI}$ and of the BDA used by enterprises. For our analysis, we focus on several European countries. We chose these countries for a few reasons. First, the number of European patent applications has been growing rapidly in the past few years, with an all-time high of about 170,000 in 2018, as reported by the European Patent Office (EPO)[1]. Second, the literature (Kumar, 1996) highlights that European companies are strongly characterized by a high rate of intellectual property activities. Third, from a practical standpoint, focusing on Europe enables us to easily obtain all the data that our analysis requires by taking advantage of the Eurostat data set, and in particular, of the Community Innovation Survey (CIS) for innovation and technology statistics.

\subsection{Data sample}

Data are taken from the Eurostat data set mentioned earlier[2]. In particular, the data concerning $\mathrm{OI}$ is derived from the CIS, a database that provides innovation and technology statistics of European countries. Surveys are voluntary and are directly carried out by EU countries. 
The selected data set includes statistics on the country, type of innovators, economic activity and firm size. Using the CIS data set allowed us to obtain a sample that is representative of the population of active EU companies, considering dimensional characteristics and different industries. The CIS data set also enabled us to explore various aspects of the innovation process according to the conceptualization proposed by Gassmann (2006). Finally, the CIS repository is used frequently among international and KM scholars (Del Giudice and Maggioni, 2014; Darroch and McNaughton, 2002; Papa et al., 2018; Kotabe and Aulakh, 2002) because of its accuracy and high data reliability.

Regarding the European countries, we include all of the 27 EU member countries, namely, Austria, Belgium, Bulgaria, Croatia, Republic of Cyprus, Czech Republic, Denmark, Estonia, Finland, France, Germany, Greece, Hungary, Ireland, Italy, Latvia, Lithuania, Luxembourg, Malta, The Netherlands, Poland, Portugal, Romania, Slovakia, Slovenia, Spain and Sweden. We also include the UK and Norway, as they are two of the most developed countries in Europe. The Eurostat data set contains yearly data from 2014 to 2019 for these 29 EU countries. Thus, we use the average of each variable over the entire study period, excluding those years for which no data are available.

\subsection{Dependent variable}

We set Patent Applications (PatApp) as the dependent variable; this variable is defined as the total number of patent applications to the EPO during the reference period.

\subsection{Independent variables}

The independent variables in our regression are as follows:

Open innovation in the sector (Openlnnov) is a variable measuring OI within the companies' sector. More specifically, it indicates the number of enterprises in each of the countries that cooperate with competitors or other enterprises in the same sector during the reference period.

Big Data Analysis (BigData) is a measure of the amount of big data used by enterprises. Specifically, we proxy it by the percentage of enterprises in each country that analyze big data generated from social media during the reference period (considering all the enterprises with ten persons employed or more, without financial sector).

\subsection{Control variables}

The following variables are included to control for the digital readiness level of every country:

$R \& D$ Expenditures $(R D)$ are the intramural expenditures on research and development activities in each country. R\&D expenditures can have a direct effect on productivity and patent (Danguy et al., 2009). We measured the total expenditure in million Euros of all R\&D activities for every country during the reference period.

ICT Training (ICTTrain) is a measure of the enterprises that provides training to improve employees' information and communications technology (ICT) skills. Specifically, it is the percentage of enterprises in each country that provides ICT training during the reference period (considering all the enterprises with ten persons employed or more, without financial sector). ICT skills together with the internet itself allow organizations access to knowledge, boosting the potential of their research activities and improving their efficiency for innovativeness (García Manjón, 2010; Wood, 2004).

Internet use (Internet) is defined as the percentage of individuals in each of the $29 \mathrm{EU}$ countries who used the internet in past three months (before the survey). 
All the variables are listed in Table 1. In addition, a block diagram that summarizes the research hypotheses and the approach followed to test them is presented in Figure 2.

\subsection{Regression model}

To test our research hypotheses, we use the following baseline regression model:

$$
\text { Patent }=\beta_{0}+\beta_{1} \text { OpenInnov }+\beta_{2} \text { BigData }+\beta_{3} \text { ICTTrain }+\beta_{4} \text { Internet }+\beta_{5} R D+\varepsilon
$$

where the $\beta$ coefficients are obtained by OLS estimation. By computing the variance inflation factors (Wooldridge, 2002), we confirmed that there are no multi-collinearity issues (we obtain VIFs smaller than or equal to 2.22). Moreover, following a common approach to test the statistical significance of the regression coefficients, standard errors are computed by applying the robust standard error estimator (White, 1980).

\section{Findings}

The descriptive statistics for all the regression variables are shown in Table 2. We observe that Patent has a rather large variability among the European countries, with a minimum and a maximum of 6.9 and 20201.2, respectively. Moreover, the minimum and maximum values show that the regressor variables also have a quite large degree of variability. This large

\section{Table 1 Variable names and descriptions}

Variable name

Patent

OpenInnov

BigData

$R D$

ICTTrain

Internet

\section{Description}

Number of patent applications to the EPO

Number of enterprises cooperating within the same sector

Percentage of enterprises that analyzed big data

R\&D expenditures (in million Euros)

Percentage of enterprises that provide training in ICT skills

Percentage of individuals who used the internet in the past three months

\section{Figure 2 Research designSource: Author's elaboration}

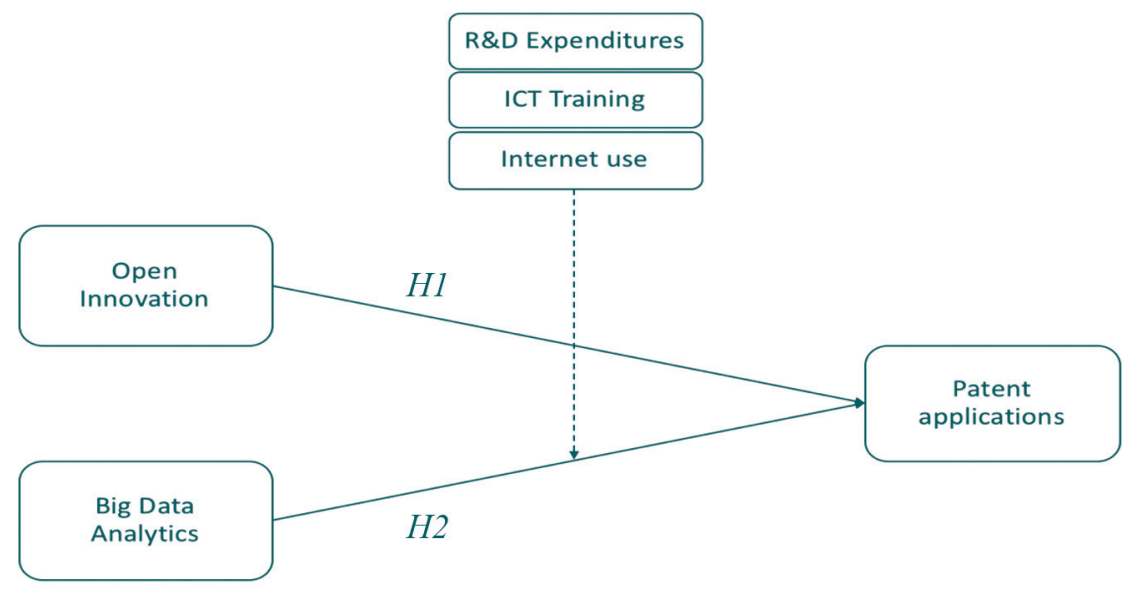

Source: Author's elaboration 
Table 2 Descriptive statistics

\begin{tabular}{lrccc} 
Variable & Mean & Standard deviation & Minimum & Maximum \\
\hline Patent & 1953.7 & 4098.7 & 6.9 & 20201.2 \\
Openlnnov & 801.2 & 1344.9 & 8 & 6868 \\
BigData & 46.6 & 10.7 & 29 & 67 \\
RD & 11132.3 & 20352.0 & 65.98 & 96319.2 \\
ICTTrain & 22.3 & 8.7 & 5 & 42.1 \\
Internet & 78.2 & 11.7 & 55.1 & 95.9
\end{tabular}

variability is not as surprising, if we consider that our data set includes very small countries such as Malta and much bigger countries, such as France and Germany.

Before running the regression analysis, we determined the Pearson's correlation coefficients of the variables (Table 3). Correlation coefficients can indicate which of the used regressors have a significant association with the number of patent applications. In particular, Patent has a large positive correlation with both $R D(0.9888)$ and Open/nnov (0.5614). Therefore, we can expect to find a positive and significant association between the number of patent applications and the R\&D expenditure, as well as a positive association between the number of patent applications and the amount of OI. In contrast, the correlation between Patent and BigData is quite small $(-0.1088)$, indicating that the number of patent applications is not associated with the use of BDA (the following regression analysis will confirm this on a rigorous statistical basis).

Finally, it is interesting to observe that the correlation between Open/nnov and $R D$ is quite strong and positive (0.6583).

The results of the regression analysis are reported in Table 4. First, we observe that, overall, the regression is statistically significant with a $p$-value (associated with the F-statistic) smaller than 0.01. We also observe that the linear regression used is overall statistically

\section{Table 3 Pearson's correlations}

\begin{tabular}{lcccccc} 
Variable & Patapp & OpenInnov & Bigdata & RD & ICTTrain & Internet \\
\hline Patent & \multicolumn{1}{c}{1} & - & - & - & - & - \\
OpenInnov & 0.5614 & 1 & - & - & - & - \\
BigData & -0.1088 & 0.2052 & 1 & - & - & - \\
RD & 0.9888 & 0.6583 & -0.0642 & 1 & - & - \\
ICTTrain & 0.2026 & 0.1652 & 0.3430 & 0.2265 & 1 & - \\
Internet & 0.2836 & 0.2818 & 0.3186 & 0.3046 & 0.7167 & 1
\end{tabular}

\section{Table 4 Regression results}

\begin{tabular}{lr} 
Variable & $\beta$ \\
\hline Constant & -256.5 \\
Openlnnov & $-0.486^{* * *}$ \\
BigData & -0.175 \\
$R D$ & $0.221^{* * *}$ \\
ICTTrain & -14.859 \\
Internet & 6.174 \\
F-stat & $766.7^{* * *}$ \\
$R^{2}$ & 0.992 \\
Adjusted $R^{2}$ & 0.991 \\
Note: ${ }^{*} ;{ }^{* *} ; * *$ denote significance at the $10 \%, 5 \%$ and $1 \%$ levels, respectively &
\end{tabular}


significant. Moreover, the proportion of the variance of the dependent variable that the regression is capable of predicting is high, as the $R^{2}$ is greater than 0.9. This means that the linear regression model is a good fit for the empirical data. The coefficient of Open/nnov is negative and highly significant (at a 0.01 level), which indicates that higher amounts of $\mathrm{OI}$ are associated with smaller numbers of patent applications. $H_{1}$ is therefore supported. Specifically, the negative relationship between Patent and Openlnnov has relevant implications, which will be discussed in Section 5.

The regression coefficient of BigData is not statistically significant, which suggests that there is no association between the use of big data and the number of patent applications. These results do not support $\mathrm{H}_{2}$.

The number of patent applications is also positively and significantly associated with R\&D expenditure at a 0.01 level. This is in accordance with the large correlation coefficient between Patent and RD that was reported previously.

There is no significant association between Patent and the remaining control variables (ICTTrain and Internet). As a further check, we performed another linear regression, in which these two control variables were removed. The results (not reported in this document) are very similar to those of the analysis including ICTTrain and Internet. Therefore, we can conclude that our findings are robust to the exclusion of control variables related to the skills and the familiarity of firms' personnel with ICT.

Finally, to summarize the results, Table 5 shows the associations that we have found between the dependent variables and each of the independent and control variables.

\section{Discussion and concluding remarks}

The main purpose of this study is to investigate the impact of OI modes and BDA on RKE in complex collaborative networks. To accomplish this, we investigate the connection between the number of patent applications and the extent of $\mathrm{OI}$, as well as the connection between the number of patent applications and the use of BDA. Specifically, we perform an empirical investigation to test two main hypotheses, based on KM and OI. The results show that the number of patent applications is positively associated with the amount of OI. Moreover, there is no significant connection between the number of patent applications and the use of BDA. Our analysis and its results contribute to knowledge regarding the impact of innovation collaborations on reflective knowledge creation, knowledge access, knowledge exchange and knowledge application within interorganizational contexts in Europe.

We are conscious that previous literature has hardly addressed how the distance in the dissemination of knowledge among the actors involved in open collaborations could foster inventiveness and innovation (Majchrzak et al., 2005; Meng et al., 2019; Zeithaml et al., 2002). However, the findings of the present study suggest that OI collaboration modes have a significant effect on innovation performance, which stimulates the pursuit of RKE. Although the subject of knowledge and innovation in internal R\&D departments is typically studied, the exploration of new knowledge is receiving growing attention in the literature because of the depreciation of internal knowledge and the prominence of innovation

\section{Table 5 Relationships with the dependent variable}

\begin{tabular}{lll} 
Regressors & Variable & Relationship with Patent \\
\hline Independent variables & Openlnnov & Significantly and negatively related \\
& BigData & Not significantly related \\
Control variables & RD & Significantly and positively related \\
& ICTTrain & Not significantly related \\
& Internet & Not significantly related
\end{tabular}


outside the firms (Chesbrough and Crowther, 2006; Jeppesen and Lakhani, 2010; Garriga et al., 2013). Participation in collaborative networks combines external knowledge search with familiar internal knowledge, leading to more diverse innovations within firms (Almirall and Casadesus-Masanell, 2010; Dahlander et al., 2016; Kafouros and Forsans, 2012). Following Laursen and Salter (2006), our proposed model for addressing OI alliances is focused mainly on the knowledge width neglecting the wisdom of knowledge exchange, as it may reveal the relationship between innovation effectiveness and external knowledge acquisition more clearly than other measures (Katila and Ahuja, 2002).

Only $H 1$ is supported by the results. As for $H 2$, the results show no evidence of a direct correlation between the use of BDA and the number of patent applications; they further indicate that among the control variables, only R\&D expenditure can explain the reflection of knowledge in inbound collaborative relationships.

Our results confirm those of an existing study showing a stronger and more significantly negative relationship between OI modes and formal knowledge creation modes (Santoro et al., 2018). These findings highlight the importance of external knowledge sourcing for improving innovation efficiency and affecting innovation performance positively, which is consistent with numerous previous Ol studies (Ahn et al., 2015; Scuotto et al., 2017; Van de Vrande et al., 2009).

Our results verify that firms engaged in Ol collaboration gain a competitive advantage by capitalizing shared knowledge through collaborative activities, which encourages them to progressively develop new products and investigate new innovation opportunities (Del Vecchio et al., 2018; Hurmelinna-Laukkanen, 2011; Jiménez-Jiménez et al., 2014).

This is especially beneficial for both multinational enterprises (MNEs) and small to medium enterprises (SMEs) that can enhance their competitive advantage and gain reverse knowledge flows by selecting appropriate $\mathrm{OI}$ modes and effective KM partners (Buckley and Carter, 2002; Ferraris et al., 2017b; Oliva and Kotabe, 2019; Van de Vrande et al., 2009).

Although mainstream literature explores the antecedents of $\mathrm{Ol}$ and the outcomes of external knowledge sources, it is not completely clear how different inbound OI modes affect the new product development at the industry level (Von Hippel, 1978; Mudambi et al., 2014; Kotabe and Murray, 2018). This study finds Ol collaboration to not only be an important driver of innovation performance but also be related to the effectiveness of R\&D expenditures. The greater the RKE success, the smaller the need to protect intellectual property. This depends on absorptive and desorptive capacities (Dell'Anno and Del Giudice, 2015; Sarala et al., 2016; Matricano et al., 2019) and also confirms that firms cannot assimilate inbound and outbound OI practices, as advancing in product and services development requires high inclusiveness in the value capture mechanisms. Even if interorganizational collaborations could significantly contribute to generating and transferring new knowledge, firms involved in these relationships are exposed to some criticalities, such as involuntarily knowledge dispersion. Although the subject has been addressed in previous studies, our findings highlight how OI encourages collaborative knowledge access. In particular, they suggest that an effective R\&D partnership strongly impacts appropriate knowledge manipulation, organizational learning, knowledge sharing processes and firms' cooperation, by reducing the effect of negative spillover among partners (Romano et al., 2014; Kesteloot and Veugelers, 1995; Gassmann, 2006; Martin and Salomon, 2003).

As already stated, our study brings three main contributions to KM literature. First, as previous studies have focused mainly on $\mathrm{KM}$ practices, we extend the literature by shifting the attention from $\mathrm{KM}$ practices to the relationship between $\mathrm{KM}$ processes and $\mathrm{OI}$. It is worth observing that among all the control variables, R\&D expenditure is the only one found to be significant for $\mathrm{Ol}$ efficiency. This implies that a high propensity for exploration can 
stimulate the shared innovation process (Gibson and Birkinshaw, 2004). Otherwise, R\&D could support the search for heterogeneous knowledge sources when exploration is open and decrease it when the innovation output is a patent. Many firms have increased their patent activity to defend their specific internal innovation and others have created industrial liaison offices and technology transfer offices to support the exploration and execution of their own innovation results (Chakravarthy, 1997; Del Giudice et al., 2014; Spender et al., 2017).

Second, our findings confirm that organizations need to use more knowledge creation and knowledge access practices that contribute to new product development. This suggests that inbound $\mathrm{OI}$ modes are very appropriate for knowledge access and knowledge transfer, stimulating high-intensity learning interactions (Scuotto et al., 2020). Our results are also consistent with recent literature that points out the increase of both supported knowledge dissemination and research productivity and innovation (Hewitt-Dundas, 2012; VeerRamjeawon and Rowley, 2019). There are two possible reasons for this. On the one hand, Ol allows firms to face new problems in addressing intellectual properties and knowledge allocation among partners, thus improving efficiency and reducing R\&D expenditures (Davenport and Prusak, 1998; Newell et al., 2003; Mintzberg, 1993). On the other hand, knowledge dissemination has no impact on financial statements, only on absorptive capacity (i.e. the knowledge base) and innovation efficiency (Malhotra et al., 2005; Malhotra and Majchrzak, 2014). Therefore, the larger the absorptive capacity of an industrial partner, the higher the motivation and engagement in inbound Ol. Accordingly, organizations may also turn tacit knowledge into explicit knowledge (Rowley, 2000; Pirkkalainen and Pawlowski, 2014).

Third, our findings suggest that adopting OI strategies can intensify efficiency and efficacy in knowledge access by minimizing the risk of negative spillover and augmenting the knowledge base among the firms' partners, regardless of the different stages of the development. This is usually considered a core asset value for successful innovation (Scuotto et al., 2017a). Based upon these considerations, we state that the role of inbound Ol practice is a vital topic to investigate, even if it has been rather neglected in previous studies (Lichtenthaler, 2009; Vrontis et al., 2017).

Considering our hypotheses, our results yield an original contribution. Furthermore, in line with mainstream literature (Davenport and Prusak, 1998; Ambrosini and Bowman, 2009; Soto-Acosta et al., 2018; Teece et al., 2016), we find that ICT and digital capabilities have no discernible effect on the number of patent applications. This confirms a limited impact on knowledge creation and knowledge appropriation processes. This result also confirms the preference for inbound rather than outbound relationships in RKE processes.

\subsection{Management and policy implications}

To summarize our contributions, this article has both practical and theoretical implications, as it contributes toward the understanding of RKE, which emerged as a key mechanism for firms spending more time and effort on the innovation process. Additionally, in line with our research design, the need for access and sharing knowledge from the external environment encourages firms to engage in collaborative relationships with outside partners. This fact leads to some interesting theoretical and managerial implications.

Our analysis presents an implication that is very relevant for practitioners, managers and policymakers. Companies should extend the boundaries of their organization by initiating and sustaining OI alliances across the value chain (Tallman and Chacar, 2011). Under a knowledge intensive and digital competition, this is mostly because of the fact that the innovation and value creation process suffers from short technology and product life cycles. In contrast, OI fosters perpetual product and service development in a complex competition network where innovation and knowledge activities are globally dispersed (Merritt, 1974; 
Kotabe and Kothari, 2016). In this vein, companies should consider balancing the costs and benefits of knowledge exchange in OI relationships. This implies that firms should actively participate and interact with other firms across value creation networks to generate useful knowledge procurement through collective and multiple sources and forms (Yoon and Hughes, 2016; O'Mahoney et al., 2013).

Complex collaborative networks are important knowledge incubators that can connect knowledge and technological providers from different countries (Singh, 2005). Participating enterprises can gain several advantages regarding managing new experiences and learning new practices, rather than reducing the risk of negative spillover. This will increase the creation of new knowledge and improve the innovation process. As absorptive capacity represents the knowledge base of enterprises, RKE is also an important mechanism that affects the firms' ability to innovate by increasing access to and the use of external knowledge on both intraorganizational and firm levels. Conversely, it also acquires and facilitates the creation of new knowledge from the networks (De Long and Fahey, 2000).

Another implication is related to the effect of the absorptive capacity. In particular, the fact that the correlation between Open/nnov and $R D$ is very large suggests that a network collaboration increases training and incentives for R\&D expenditure, including firms with a low knowledge base who can make full use of their absorptive capacity for innovation through RKE. In this vein, open alliances help firms to import advanced knowledge from abroad that could otherwise not be explored directly, except through high-risk and unsustainable R\&D investments.

Finally, the effects of RKE on innovation performance may also have implications on a macro level. It may sustain the formulation of government trade policies that stimulate alternative knowledge ownership mechanisms, incentivizing the adoption of Ol solutions. This is especially valid for developing countries and SMEs (Malhotra et al., 2017). Accordingly, our findings confirm those of previous studies that emphasize a positive momentum between the internalization of knowledge and innovation creation (Chen and Wang, 2006; Xu et al., 2010; Vahlne and Johanson, 2013). This consideration also highlights another relevant implication for KM and innovation. The firm's ability to access, exchange and receive knowledge from complex collaborative networks depends upon not only the effectiveness of interorganizational collaboration but also on the corporate knowledge base. This is related to R\&D expenditure and the firm's absorptive and desorptive capabilities that support product development by reusing and recombining knowledge for different innovation processes. This confirms firms' pursuit of organizational flexibility and strategic agility, already widely confirmed in the literature (Kotabe and Mudambi, 2009; Oliva et al., 2019; Shams et al., 2020; Weber and Tarba, 2014).

\subsection{Theoretical contributions}

From a theoretical point of view, the manuscript contributes to the existing literature by answering the call for a better understanding of KM and innovation literature. Specifically, the study aims to elucidate the role of OI collaboration modes in the process of knowledge dissemination, based on an international cross-industry perspective (Alavi and Leidner, 2001; Cavusgil and Knight, 2015). The originality of the present study can be seen from the perspective of international management. It emphasizes the relevance of innovation capabilities and absorptive capacity for new and external sources of knowledge (Ahammad et al., 2016; Del Giudice et al., 2017). International business requires new organizational structures that can make firms more efficient in complex and volatile environments. Therefore, various companies that operate in international networks that involve knowledgesharing strategies with partners value the development of products and services innovation (Bennis and Nanus, 1985; Caputo et al., 2019). New corporate structures deliver a fresh combination of collaborative networks and diverse innovation bases that are useful for 
integrating open, digital and global KM practices into firms (Cheng and Fu, 2013; Dyer and Singh, 1998; du Plessis, 2007).

Beyond knowledge appropriation mechanisms, this study suggests that focusing on patent application is not sufficient to ensure a firms' responsiveness in the long run (Inkinen, 2016). This relevant implication infers that academics should consider the drivers affecting interorganizational collaboration over time. In particular, ideas and interorganizational knowledge seem to stimulate knowledge aggregation and innovation creation within networks. In this regard, we recognize that OI collaboration could offer a number of opportunities to build specific knowledge transfer capabilities, leading to improved innovation efficiency. This implication is intriguing, as it consecrates that the effective exploitation of external knowledge depends on a firm's absorptive capacity (Kotabe et al., 2014; Khan et al., 2016). This may be because collaborating firms have more knowledge and research capacity to learn and capitalize on imported knowledge (Oliva et al., 2019).

Finally, our study addresses how managers should exploit the reflectiveness of knowledge in cooperative learning by combining internal and external knowledge sources. From this perspective, the firm's absorptive capacity must shift to desorptive capacity through a decodification process that prepares the firm for an internal change to interorganizational dynamic capabilities (Teece et al., 1997; Kothari et al., 2013; Dell'Anno and Del Giudice, 2015; Sarala et al., 2016). In this regard, knowledge co-creation because of Ol collaboration adds a new level to a firm's competitiveness, encouraging researchers to consider RKE as an interesting topic - not only for MNEs but also among collaborative networks - and as a transformative KM practice for externally dispersed knowledge allocation (Oliva and Kotabe, 2019; Andreeva and Kianto, 2012).

Knowledge sharing increases the effectiveness of innovation for the companies involved, whereas knowledge access stimulates quality product and service development (Cheng and $\mathrm{Fu}, 2013$ ). Our findings fill the theoretical gap regarding the accumulation of knowledge, reducing the impact of knowledge obsolescence in intellectual property rights (Marra et al., 2012; Oliva, 2014). This interpretation can be seen as a crossroad for future research in management disciplines.

\subsection{Boundaries and future research directions}

This study has certain limitations, which we will address further. We also establish directions for future studies in the researched area.

Despite the appropriateness of the methodology, the main limitation of this quantitative study is well established in management literature; we cannot overlook the questions of "how" and "why" firms encourage individual search for sharing ideas and knowledge. Hence, a qualitative study should further investigate the micro-foundations of the above relationships. In a sense, our study can also be considered a meta-analysis that aims to interpret RKE among cooperative and complex networks (Tallman and Chacar, 2011; Del Giudice et al., 2017). The rest of the limitations are as follows: first, our research is a first effort to investigating this aspect. Using data from non-European countries or undertaking some comparative studies across different contexts could increase our study's generalizability. Second, our research focuses on a specific European panel and ignores the differences in the sample composition at firm level (i.e. domestic vs international, SMEs vs MNEs, manufacturing vs digital and public vs private companies). Future studies should focus on the effect of companies' characteristics on innovation modes. Third, we acknowledge that our investigation does not directly measure the intensity and impact of related external search of knowledge on innovation patent activities. A more robust analysis of this should be done in future. 
Other research contributions that go beyond the scope of the present study are as follows. First, investigating the impact of other variables such as internationalization, market orientation or learning orientation will add value to existing knowledge. Moreover, it might be interesting to extend our analysis to also consider variables related to management (such as homogeneity of dynamic capabilities and absorptive capacity) and organization aspects (such as formal vs informal collaboration modes and intra vs inter-organizational networks) (Castaneda et al., 2018; Knight and Cavusgil, 2004).

Finally, our empirical investigation does not investigate whether the dissemination of knowledge in inbound OI collaboration leads to superior innovation performances. Hence, future research should aim to provide a clear picture of how the Ol dynamics influence the accrual of knowledge in complex collaborative networks.

\section{Notes}

1 Report EPO 2019, see the website https://www.epo.org/news-issues/news/2019/20190312.html

2 Eurostat is the statistical office of the EU, see the official Eurostat website at http://ec.europa.eu/ eurostat

\section{References}

Ahammad, M., Tarba, S.Y., Liu, Y. and Glaister, K. (2016), "Knowledge transfer and cross-border acquisition performance: the impact of cultural distance and employee retention", International Business Review, Vol. 25 No. 1, pp. 66-75.

Ahn, J.M., Minshall, T. and Mortara, L. (2015), "Open innovation: a new classification and its impact on firm performance in innovative SMEs", Journal of Innovation Management, Vol. 3 No. 2, pp. 33-54.

Akter, S. and Wamba, S.F. (2016), "Big data analytics in E-commerce: a systematic review and agenda for future research", Electronic Markets, Vol. 26 No. 2, pp. 173-194., doi: 10.1007/s12525-016-0219-0.

Akter, S., Wamba, S.F., Gunasekaran, A., Dubey, R. and Childe, S.J. (2016), "How to improve firm performance using big data analytics capability and business strategy alignment?", International Journal of Production Economics, Vol. 182, pp. 113-131., doi: 10.1016/j.ijpe.2016.08.018.

Alavi, M. and Leidner, D.E. (2001), "Review: knowledge management and knowledge management systems: conceptual foundations and research issues", MIS Quarterly, Vol. 25 No. 1, pp. 107-136.

Alexy, O., Criscuolo, P. and Salter, A. (2009), "Does IP strategy have to cripple open innovation?", MIT Sloan Management Review, Vol. 51 No. 1, pp. 71-77.

Almirall, E. and Casadesus-Masanell, R. (2010), "Open versus closed innovation: a model of discovery and divergence", Academy of Management Review, Vol. 35 No. 1, pp. 27-47.

Ambrosini, V. and Bowman, C. (2009), "What are dynamic capabilities and are they a useful construct in strategic management?", International Journal of Management Reviews, Vol. 11 No. 1, pp. 29-49.

Andreeva, T. and Kianto, A. (2012), "Does knowledge management really matter? Linking KM practices, competitiveness and economic performance", Journal of Knowledge Management, Vol. 16 No. 4, pp. 617-636.

Battistella, C., Colucci, K., De Toni, A.F. and Nonino, F. (2013), "Methodology of business ecosystems network analysis: a case study in telecom Italia future Centre", Technological Forecasting and Social Change, Vol. 80 No. 6, pp. 1194-1210.

Bennis, W. and Nanus, B. (1985), Leaders: Strategies for Taking Charge, Harper \& Row, New York, NY.

Bianchi, M., Cavaliere, A., Chiaroni, D., Frattini, F. and Chiesa, V. (2011), "Organisational modes for open innovation in the bio-pharmaceutical industry: an exploratory analysis", Technovation, Vol. 31 No. 1, pp. 22-33., doi: 10.1016/j.technovation.2010.03.002.

Bogers, M., Afuah, A. and Bastian, B. (2010), "Users as innovators: a review, critique, and future research directions", Journal of Management, Vol. 36 No. 4, pp. 857-875., doi: 10.1177/0149206309353944. 
Braganza, A., Brooks, L., Nepelski, D., Ali, M. and Moro, R. (2017), "Resource management in big data initiatives: processes and dynamic capabilities", Journal of Business Research, Vol. 70, pp. 328-337.

Buckley, P.J. and Carter, M.J. (2002), "Process and structure in knowledge management practices of British and US multinational enterprises", Journal of International Management, Vol. 8 No. 1, pp. 29-48., doi: 10.1016/S1075-4253(01)00051-5.

Bughin, J., Chui, M. and Johnson, B. (2008), "The next step in open innovation”, The McKinsey Quarterly, Vol. 4 No. 6, pp. 1-8.

Caputo, F., Garcia-Perez, A., Cillo, V. and Giacosa, E. (2019), "A knowledge-based view of people and technology: directions for a value co-creation-based learning organization", Journal of Knowledge Management, Vol. 23 No. 7, pp. 1314-1334.

Castaneda, D.I., Manrique, L.F. and Cuellar, S. (2018), "Is organizational learning being absorbed by knowledge management? A systematic review", Journal of Knowledge Management, Vol. 22 No. 2, pp. 299-325.

Cavusgil, S.T. and Knight, G.A. (2015), "The born global firm: an entrepreneurial and capabilities perspective on early and rapid internationalization", Journal of International Business Studies, Vol. 46 No. 1, pp. 3-16.

Chakravarthy, B. (1997), "A new strategy framework for coping with turbulence", MIT Sloan Management Review, Vol. 38 No. 2, pp. 69-82.

Chen, H., Chiang, R.H. and Storey, V.C. (2012), "Business intelligence and analytics: from big data to big impact", MIS Quarterly, pp. 1165-1188, doi: 10.1145/2463676.2463712.

Cheng, J.H. and Fu, Y.C. (2013), "Inter-organizational relationships and knowledge sharing through the relationship and institutional orientations in supply chains", International Journal of Information Management, Vol. 33 No. 3, pp. 473-484.

Chen, J. and Wang, F.R. (2006), "A research on synergistic innovation mechanism between technological innovation and market innovation in China - based on relational analysis of environment, management, and innovation [J]", Studies in Science of Science, 4.

Chesbrough, H., Vanhaverbeke, W. and West, J. (Eds) (2014), New Frontiers in Open Innovation, Oup Oxford.

Chesbrough, H. (2007), "The market for innovation: implications for corporate strategy", California Management Review, Vol. 49 No. 3, pp. 45-66., doi: 10.1177/000812560704900301.

Chesbrough, H.W. (2003), Open Innovation: The New Imperative for Creating and Profiting from Technology, Harvard Business Press, Boston, MA.

Chesbrough, H. and Crowther, A.K. (2006), "Beyond high tech: early adopters of open innovation in other industries", R and D Management, Vol. 36 No. 3, pp. 229-236.

Clark, T.H. and Stoddard, D.B. (1996), "Interorganizational business process redesign: merging technological and process innovation", Journal of Management Information Systems, Vol. 13 No. 2, pp. 9-28.

Dahlander, L., O'Mahony, S. and Gann, D.M. (2016), "One foot in, one foot out: how does individuals' external search breadth affect innovation outcomes?", Strategic Management Journal, Vol. 37 No. 2, pp. 280-302.

Danguy, J., D Rassenfosse, G. and van Pottelsberghe de la Potterie, B. (2009), "The R\&D-patent relationship: an industry perspective", EIB Papers, European Investment Bank (EIB), Luxembourg, Vol. 14 No. 1, pp. 170-195.

Darlington, R.B. and Hayes, A.F. (2016), "Regression analysis and linear models: concepts", Applications, and Implementation, Guilford Publications, New York, NY.

Darroch, J. and McNaughton, R. (2002), "Examining the link between knowledge management practices and types of innovation", Journal of Intellectual Capital, Vol. 3 No. 3, pp. 210-222.

Davenport, T.H. and Prusak, L. (1998), "Working Knowledge: How Organizations Manage What They Know, Harvard Business Press, Boston, MA.

Davenport, T.H., Barth, P. and Bean, R. (2012), "How 'big data' is different", MIT Sloan Management Review, Vol. 54 No. 1, pp. 22-24. 
De Dreu, C.K. and West, M.A. (2001), "Minority dissent and team innovation: the importance of participation in decision making", Journal of Applied Psychology, Vol. 86 No. 6, pp. 1191-1201., doi: 10.1037/0021-9010.86.6.1191.

De Long, D.W. and Fahey, L. (2000), "Diagnosing cultural barriers to knowledge management", Academy of Management Perspectives, Vol. 14 No. 4, pp. 113-127.

de Zubielqui, G.C., Lindsay, N., Lindsay, W. and Jones, J. (2019), "Knowledge quality, innovation and firm performance: a study of knowledge transfer in SMEs", Small Business Economics, Vol. 53 No. 1, pp. 145-164.

Del Giudice, M. and Maggioni, V. (2014), "Managerial practices and operative directions of knowledge management within inter-firm networks: a global view", Journal of Knowledge Management, Vol. 18 No. 5 , pp. 841-846., doi: 10.1108/JKM-06-2014-0264.

Del Giudice, M., Carayannis, E.G. and Maggioni, V. (2017), "Global knowledge intensive enterprises and international technology transfer: emerging perspectives from a quadruple helix environment", The Journal of Technology Transfer, Vol. 42 No. 2, pp. 229-235.

Del Vecchio, P., Di Minin, A., Petruzzelli, A.M., Panniello, U. and Pirri, S. (2018), "Big data for open innovation in SMEs and large corporations: trends, opportunities, and challenges", Creativity and Innovation Management, Vol. 27 No. 1, pp. 6-22., doi: 10.1111/caim.12224.

Dell'Anno, D. and Del Giudice, M. (2015), "Absorptive and desorptive capacity of actors within universityindustry relations: does technology transfer matter?", Journal of Innovation and Entrepreneurship, Vol. 4 No. 1, pp. 1-20.

Du Plessis, M. (2007), "The role of knowledge management in innovation", Journal of Knowledge Management, Vol. 11 No. 4, pp. 20-29.

Dyer, J.H. and Singh, H. (1998), "The relational view: cooperative strategy and sources of interorganizational competitive advantage", Academy of Management Review, Vol. 23 No. 4, pp. 660-679.

Ferraris, A., Bresciani, S. and Del Giudice, M. (2016), "International diversification and firm performance: a fourstage model”, EuroMed Journal of Business, Vol. 11 No. 3, pp. 362-375., doi: 10.1108/EMJB-10-2015-0048.

Ferraris, A., Santoro, G. and Dezi, L. (2017b), "How MNC's subsidiaries may improve their innovative performance? The role of external sources and knowledge management capabilities", Journal of Knowledge Management, Vol. 21 No. 3, pp. 540-552.

Ferraris, A., Mazzoleni, A., Devalle, A. and Couturier, J. (2018), "Big data analytics capabilities and knowledge management: impact on firm performance", Management Decision, Vol. 57 No. 8, pp. 1923-1936., doi: 10.1108/MD-07-2018-0825.

Galunic, D.C. and Rodan, S. (1998), "Resource recombinations in the firm: knowledge structures and the potential for Schumpeterian innovation", Strategic Management Journal, Vol. 19 No. 12, pp. 1193-1201.

García Manjón, J.V. (2010), "A proposal of indicators and policy framework for innovation benchmark in Europe", Journal of Technology Management \& Innovation, Vol. 5 No. 2, pp. 13-23.

Garriga, H., Von Krogh, G. and Spaeth, S. (2013), "How constraints and knowledge impact open innovation", Strategic Management Journal, Vol. 34 No. 9, pp. 1134-1144.

Gassmann, O. (2006), "Opening up the innovation process: towards an agenda", $R$ and D Management, Vol. 36 No. 3, pp. 223-228., doi: 10.1111/j.1467-9310.2006.00437.x.

Gibson, C.B. and Birkinshaw, J. (2004), "The antecedents, consequences, and mediating role of organizational ambidexterity", Academy of Management Journal, Vol. 47 No. 2, pp. 209-226.

Gold, A.H., Malhotra, A. and Segars, A.H. (2001), "Knowledge management: an organizational capabilities perspective", Journal of Management Information Systems, Vol. 18 No. 1, pp. 185-214.

Greenlee, P. and Cassiman, B. (1999), "Product market objectives and the formation of research joint ventures", Managerial and Decision Economics, Vol. 20 No. 3, pp. 115-130., doi: 10.1002/(SICI)10991468(199905)20:3<115::AID-MDE927>3.0.CO;2-V.

Guan, J. and Liu, N. (2016), "Exploitative and exploratory innovations in knowledge network and collaboration network: a patent analysis in the technological field of nano-energy", Research Policy, Vol. 45 No. 1, pp. 97-112., doi: 10.1016/j.respol.2015.08.002.

Hellwig, Z. (1963), Linear Regression and Its Application to Economics, Pergamon Press, Oxford. 
Hewitt-Dundas, N. (2012), "Research intensity and knowledge transfer activity in UK universities", Research Policy, Vol. 41 No. 2, pp. 262-275.

Hurmelinna-Laukkanen, P. (2011), "Enabling collaborative innovation-knowledge protection for knowledge sharing", European Journal of Innovation Management, Vol. 14 No. 3, pp. 303-321., doi: 10.1108/14601061111148816.

Inkinen, H. (2016), "Review of empirical research on knowledge management practices and firm performance”, Journal of Knowledge Management, Vol. 20 No. 2, pp. 230-257.

Jenssen, J.I. and Nybakk, E. (2013), "Inter-organizational networks and innovation in small, knowledge-intensive firms: a literature review", International Journal of Innovation Management, Vol. 17 No. 2, p. 1350008.

Jeppesen, L.B. and Lakhani, K.R. (2010), "Marginality and problem-solving effectiveness in broadcast search", Organization Science, Vol. 21 No. 5, pp. 1016-1033.

Jiménez-Jiménez, D., Martínez-Costa, M. and Sanz-Valle, R. (2014), "Knowledge management practices for innovation: a multinational corporation's perspective", Journal of Knowledge Management, Vol. 18 No. 5, pp. 905-918., doi: 10.1108/JKM-06-2014-0242.

Kafouros, M.I. and Forsans, N. (2012), "The role of open innovation in emerging economies: do companies profit from the scientific knowledge of others?", Journal of World Business, Vol. 47 No. 3, pp. 362-370.

Katila, R. and Ahuja, G. (2002), "Something old, something new: a longitudinal study of search behavior and new product introduction", Academy of Management Journal, Vol. 45 No. 6, pp. 1183-1194.

Kauppila, O.P. (2010), "Creating ambidexterity by integrating and balancing structurally separate interorganizational partnerships", Strategic Organization, Vol. 8 No. 4, pp. 283-312., doi: 10.1177/ 1476127010387409 .

Kennedy, P. (1998), A Guide to Econometrics, The MIT Press, Cambridge.

Kesteloot, K. and Veugelers, R. (1995), "Stable R\&D cooperation with spillovers", Journal of Economics Management Strategy, Vol. 4 No. 4, pp. 651-672., doi: 10.1111/j.1430-9134.1995.00651.x.

Khanna, T., Gulati, R. and Nohria, N. (1998), "The dynamics of learning alliances: competition, cooperation, and relative scope", Strategic Management Journal, Vol. 19 No. 3, pp. 193-210.

Khan, Z. and Vorley, T. (2017), "Big data text analytics: an enabler of knowledge management", Journal of Knowledge Management, Vol. 21 No. 1, pp. 18-34, doi: 10.1108/JKM-06-2015-0238.

Khan, Z., Rao-Nickolson, R. and Tarba, S.Y. (2016), "Global networks as a mode of balance for exploratory innovations in a late liberalizing economy", Journal of World Business, Vol. 53 No. 3, pp. 392-402.

Knight, G.A. and Cavusgil, S.T. (2004), "Innovation, organizational capabilities, and the born- global firm", Journal of International Business Studies, Vol. 35 No. 2, pp. 124-141.

Kotabe, M. and Aulakh, P. S. (Eds). (2002), Emerging Issues in International Business Research, Edward Elgar Pub.

Kotabe, M. and Kothari, T. (2016), "Emerging market multinational companies' evolutionary paths to building a competitive advantage from emerging markets to developed countries", Journal of World Business, Vol. 51 No. 5, pp. 729-743.

Kotabe, M. and Mudambi, R. (2009), "Global sourcing and value creation: opportunities and challenges", Journal of International Management, Vol. 2 No. 15, pp. 121-125.

Kotabe, M. and Murray, J.Y. (2018), "Global sourcing strategy: an evolution in global production and sourcing rationalization", Advances in Global Marketing, Springer, Cham, pp. 365-384.

Kotabe, M., Jian, C. and Murray, J. (2014), "Examining the complementary effect of political networking capability with absorptive capacity on the innovative performance of emerging market firms", Journal of Management, Vol. 43 No. 4, pp. 1131-1156.

Kothari, T., Kotabe, M. and Murphy, P. (2013), "Rules of the game for emerging market multinational companies from China and India", Journal of International Management, Vol. 19 No. 3 , pp. 276-299.

Kumar, N. (1996), "Intellectual property protection, market orientation and location of overseas R\&D activities by multinational enterprises", World Development, Vol. 24 No. 4, pp. 673-688. 
Lager, T., Rennard, J.P., Rosell, D.T., Lakemond, N. and Wasti, S.N. (2014), "Integrating knowledge with suppliers at the R\&D-manufacturing interface", Journal of Manufacturing Technology Management, Vol. 25 No. 2, pp. 240-257.

Laursen, K. and Salter, A. (2006), "Open for innovation: the role of openness in explaining innovation performance among UK manufacturing firms", Strategic Management Journal, Vol. 27 No. 2, pp. 131-150.

Lee, B., Cho, H.H. and Shin, J. (2015), "The relationship between inbound open innovation patents and financial performance: evidence from global information technology companies", Asian Journal of Technology Innovation, Vol. 23 No. 3, pp. 289-303., doi: 10.1080/19761597.2015.1120497.

Lee, S., Park, G., Yoon, B. and Park, J. (2010), "Open innovation in SMEs - an intermediated network model”, Research Policy, Vol. 39 No. 2, pp. 290-300., doi: 10.1016/j.respol.2009.12.009.

Lichtenthaler, U. (2009), "Outbound open innovation and its effect on firm performance: examining environmental influences", R\&D Management, Vol. 39 No. 4, pp. 317-330., doi: 10.1111/j.14679310.2009.00561.x.

Lichtenthaler, U. and Lichtenthaler, E. (2009), "A capability-based framework for open innovation: complementing absorptive capacity”, Journal of Management Studies, Vol. 46 No. 8, pp. 1315-1338., doi: 10.1111/j.1467-6486.2009.00854.x.

McGuire, T., Ariker, M. and Roggendorf, M. (2013), Making Data Analytics Work: Three Key Challenges, McKinsey \& Company.

Majchrzak, A., Malhotra, A. and John, R. (2005), "Perceived individual collaboration know-how development through information technology-enabled contextualization: evidence from distributed teams", Information Systems Research, Vol. 16 No. 1, pp. 9-27.

Malhotra, A. and Majchrzak, A. (2004), "Enabling knowledge creation in far-flung teams: best practices for IT support and knowledge sharing", Journal of Knowledge Management, Vol. 8 No. 4, pp. 75-88.

Malhotra, A. and Majchrzak, A. (2014), "Managing crowds in innovation challenges", California Management Review, Vol. 56 No. 4, pp. 103-123.

Malhotra, A., Gosain, S. and Sawy, O.A.E. (2005), "Absorptive capacity configurations in supply chains: gearing for partner-enabled market knowledge creation", MIS Quarterly, Vol. 29 No. 1, pp. $145-187$.

Malhotra, A., Majchrzak, A. and Niemiec, R.M. (2017), "Using public crowds for open strategy formulation: mitigating the risks of knowledge gaps", Long Range Planning, Vol. 50 No. 3, pp. 397-410.

Marra, M., Ho, W. and Edwards, J.S. (2012), "Supply chain knowledge management: a literature review", Expert Systems with Applications, Vol. 39 No. 5, pp. 6103-6110.

Martin, X. and Salomon, R. (2003), "Knowledge transfer capacity and its implications for the theory of the multinational corporation", Journal of International Business Studies, Vol. 34 No. 4, pp. 356-373.

Matricano, D., Candelo, E., Sorrentino, M. and Martínez-Martínez, A. (2019), "Absorbing in-bound knowledge within open innovation processes. The case of Fiat Chrysler automobiles", Journal of Knowledge Management, Vol. 23 No. 4, pp. 786-807.

Meng, D., Li, X. and Rong, K. (2019), "Industry-to-university knowledge transfer in ecosystem-based academic entrepreneurship: case study of automotive dynamics \& control group in Tsinghua university", Technological Forecasting and Social Change, Vol. 141, pp. 249-262.

Merritt, T.P. (1974), "Forecasting the future business environment - the state of the art", Long Range Planning, Vol. 7 No. 3, pp. 54-62.

Mintzberg, H. (1993), "The pitfalls of strategic planning", California Management Review, Vol. 36 No. 1, pp. 32-47.

Mudambi, R., Piscitello, L. and Rabbiosi, L. (2014), "Reverse knowledge transfer in MNEs: subsidiary innovativeness and entry modes", Long Range Planning, Vol. 47 Nos 1/2, pp. 49-63.

Newell, S., Huang, J.C., Galliers, R.D. and Pan, S.L. (2003), "Implementing enterprise resource planning and knowledge management systems in tandem: fostering efficiency and innovation complementarity", Information and Organization, Vol. 13 No. 1, pp. 25-52. 
Nguyen, B., Yu, X., Melewar, T.C. and Chen, J. (2015), "Brand innovation and social media: knowledge acquisition from social media, market orientation, and the moderating role of social media strategic capability", Industrial Marketing Management, Vol. 51, pp. 11-25., doi: 10.1016/j.indmarman.2015.04.017.

Nonaka, I. and Takeuchi, H. (1995), The Knowledge-Creating Company, Oxford University Press, New York, NY.

O'Leary, D.E. (2013), "Artificial intelligence and big data", IEEE Intelligent Systems, Vol. 28 No. 2, pp. 96-99., doi: 10.1109/MIS.2013.39.

Oliva, F.L. (2014), "Knowledge management barriers, practices and maturity model", Journal of Knowledge Management, Vol. 18 No. 6, pp. 1053-1074.

Oliva, F.L., Couto, M.H.G., Santos, R.F. and Bresciani, S. (2019), "The integration between knowledge management and dynamic capabilities in agile organizations", Management Decision, Vol. 57 No. 8, pp. 1960-1979.

Oliva, F. and Kotabe, M. (2019), "Barriers, practices, methods and knowledge management tools in startups", Journal of Knowledge Management, Vol. 23 No. 9, pp. 1838-1856., doi: 10.1108/JKM-06-20180361.

O'Mahoney, J., Heusinkveld, S. and Wright, C. (2013), "Commodifying the commodifiers: the impact of procurement on management knowledge", Journal of Management Studies, Vol. 50 No. 2, pp. 204-235.

Papa, A., Dezi, L., Gregori, G.L., Mueller, J. and Miglietta, N. (2018), "Improving innovation performance through knowledge acquisition: the moderating role of employee retention and human resource management practices", Journal of Knowledge Management, Vol. 24 No. 3, pp. 589-605.

Philip, J. (2018), "An application of the dynamic knowledge creation model in big data", Technology in Society, Vol. 54, pp. 120-127.

Pirkkalainen, H. and Pawlowski, J.M. (2014), "Global social knowledge management-understanding barriers for global workers utilizing social software", Computers in Human Behavior, Vol. 30, pp. 637-647.

Romano, M., Del Giudice, M. and Nicotra, M. (2014), "Knowledge creation and exploitation in Italian universities: the role of internal policies for patent activity", Journal of Knowledge Management, Vol. 18 No. 5, pp. 952-970.

Rowley, J. (2000), "From learning organisation to knowledge entrepreneur", Journal of Knowledge Management, Vol. 4 No. 1, pp. 7-15.

Santoro, G., Bresciani, S. and Papa, A. (2018), "Collaborative modes with cultural and creative industries and innovation performance: the moderating role of heterogeneous sources of knowledge and absorptive capacity", Technovation, Vol. 92-93

Sarala, R.M., Cooper, C., Junni, P. and Tarba, S. (2016), "A socio-cultural perspective on knowledge transfer in mergers and acquisitions", Journal of Management, Vol. 42 No. 5, pp. 1230-1249.

Scuotto, V., Beatrice, O., Cillo, V., Nicotra, M., Di Gioia, L. and Briamonte, M.F. (2020), "Uncovering the micro-foundations of knowledge sharing in open innovation partnerships: an intention-based perspective of technology transfer", Technological Forecasting and Social Change, Vol. 152

Scuotto, V., Del Giudice, M., Bresciani, S. and Meissner, D. (2017), "Knowledge-driven preferences in informal inbound open innovation modes. An explorative view on small to medium enterprises", Journal of Knowledge Management, Vol. 21 No. 3, pp. 640-655., doi: 10.1108/JKM-10-2016-0465.

Shah, S., Horne, A. and Capellá, J. (2012), "Good data won't guarantee good decisions", Harvard Business Review, Vol. 90 No. 4, pp. 23-25.

Shams, R., Vrontis, D., Belyaeva, Z., Ferraris, A. and Czinkota, M.R. (2020), "Strategic agility in international business: a conceptual framework for "agile" multinationals", Journal of International Management, p. 100737.

Shi, X., Zhang, Q. and Zheng, Z. (2019), "The double-edged sword of external search in collaboration networks: embeddedness in knowledge networks as moderators", Journal of Knowledge Management, Vol. 23 No. 10, pp. 2135-2160., doi: 10.1108/JKM-04-2018-0226.

Singh, J. (2005), "Collaborative networks as determinants of knowledge diffusion patterns", Management Science, Vol. 51 No. 5, pp. 756-770.

Soto-Acosta, P., Popa, S. and Martinez-Conesa, I. (2018), "Information technology, knowledge management and environmental dynamism as drivers of innovation ambidexterity: a study in SMEs", Journal of Knowledge Management, Vol. 22 No. 4, pp. 931-948. 
Spender, J.C., Corvello, V., Grimaldi, M. and Rippa, P. (2017), "Startups and open innovation: a review of the literature”, European Journal of Innovation Management, Vol. 20 No. 1, pp. 4-30.

Stock, J.H. and Watson, M.W. (2003), Introduction to Econometrics, Prentice Hall, New York, NY.

Tallman, S. and Chacar, A.S. (2011), "Communities, alliances, networks and knowledge in multinational firms: a micro-analytic framework", Journal of International Management, Vol. 17 No. 3, pp. 201-210.

Teece, D.J., Peteraf, M. and Leih, S. (2016), "Dynamic capabilities and organizational agility: risk, uncertainty, and strategy in the innovation economy", California Management Review, Vol. 58 No. 4, pp. 13-35.

Teece, D.J., Pisano, G. and Shuen, A. (1997), "Dynamic capabilities and strategic management", Strategic Management Journal, Vol. 18 No. 7, pp. 509-533.

Terwiesch, C. and Xu, Y. (2008), "Innovation contests, open innovation, and multiagent problem solving", Management Science, Vol. 54 No. 9, pp. 1529-1543., doi: 10.1287/mnsc.1080.0884.

Tong, X. and Frame, J.D. (1994), "Measuring national technological performance with patent claims data", Research Policy, Vol. 23 No. 2, pp. 133-141.

Vahlne, J.E. and Johanson, J. (2013), "The Uppsala model on evolution of the multinational business enterprise-from internalization to coordination of networks", International Marketing Review, Vol. 30 No. 3, pp. 189-210

Van de Vrande, V., De Jong, J.P., Vanhaverbeke, W. and De Rochemont, M. (2009), "Open innovation in SMEs: trends, motives and management challenges", Technovation, Vol. 29 Nos 6/7, pp. 423-437, doi: 10.1016/j.technovation.2008.10.001.

Van der Meer, H. (2007), "Open innovation-the Dutch treat: challenges in thinking in business models", Creativity and Innovation Management, Vol. 16 No. 2, pp. 192-202., doi: 10.1111/j.14678691.2007.00433.x.

Veer-Ramjeawon, P. and Rowley, J. (2019), "Embedding knowledge management in higher education institutions (HEIs): a comparison between two countries", Studies in Higher Education, pp. 1-17.

Veugelers, M., Bury, J. and Viaene, S. (2010), "Linking technology intelligence to open innovation", Technological Forecasting and Social Change, Vol. 77 No. 2, pp. 335-343.

Von Hippel, E. (1978), "Successful industrial products from customer ideas: presentation of a new customer-active paradigm with evidence and implications", Journal of Marketing, Vol. 42 No. 1, pp. 39-49., doi: 10.1177/002224297804200109.

Von Hippel, E. (1986), "Lead users: a source of novel product concepts", Management Science, Vol. 32 No. 7, pp. 791-805

Vrontis, D., Thrassou, A., Santoro, G. and Papa, A. (2017), "Ambidexterity, external knowledge and performance in knowledge-intensive firms", The Journal of Technology Transfer, Vol. 42 No. 2, pp. 374-388.

Weber, Y. and Tarba, S.Y. (2014), "Strategic agility: a state of the art introduction to the special section on strategic agility", California Management Review, Vol. 56 No. 3, pp. 5-12., doi: 10.1525/cmr.2014.56.3.5.

West, J., Salter, A., Vanhaverbeke, W. and Chesbrough, H. (2014), "Open innovation: the next decade", Research Policy, Vol. 43 No. 5, pp. 805-881., doi: 10.1016/j.respol.2014.03.001.

White, H. (1980), "A heteroscedasticity-consistent covariance matrix and a direct test for heteroscedasticity", Econometrica, Vol. 48 No. 4, pp. 817-838.

Wood, C.M. (2004), "Marketing and e-commerce as tools of development in the Asia-pacific region: a dual path", International Marketing Review, Vol. 21 No. 3, pp. 301-320.

Wooldridge, J.M. (2002), Econometrics Analysis of Cross Section and Panel Data, The MIT Press, Cambridge.

Xu, J., Houssin, R., Caillaud, E. and Gardoni, M. (2010), "Macro process of knowledge management for continuous innovation", Journal of Knowledge Management, Vol. 14 No. 4, pp. 573-591.

Yoon, E. and Hughes, S. (2016), Big Companies Should Collaborate with Startups, Harvard Business Review, Boston.

Yun, J.J., Jeong, E. and Park, J. (2016), "Network analysis of open innovation”, Sustainability, Vol. 8 No. 8 , pp. 729, doi: 10.3390/su8080729. 
Zeithaml, V.A., Parasuraman, A. and Malhotra, A. (2002), "Service quality delivery through web sites: a critical review of extant knowledge", Journal of the Academy of Marketing Science, Vol. 30 No. 4, pp. 362-375

Zhang, T., Wang, W.Y.C. and Pauleen, D.J. (2017), "Big data investments in knowledge and nonknowledge intensive firms: what the market tells us", Journal of Knowledge Management, Vol. 21 No. 3, pp. 623-639.

\section{Further reading}

Boudreau, M.C., Gefen, D. and Straub, D.W. (2001), "Validation in information systems research: a stateof-the-art assessment", MIS Quarterly, Vol. 25 No. 1, pp. 1-16.

Buckley, P.J. (2002), "Is the international business research agenda running out of steam?", Journal of International Business Studies, Vol. 33 No. 2, pp. 365-373.

Mudambi, R. (2002), "Knowledge management in multinational firms", Journal of International Management, Vol. 8 No. 1, pp. 1-9.

Nicotra, M., Romano, M. and Del Giudice, M. (2014), "The evolution dynamic of a cluster knowledge network: the role of firms' absorptive capacity", Journal of the Knowledge Economy, Vol. 5 No. 1, pp. 70-93.

Samuel, K.E., Goury, M.L., Gunasekaran, A. and Spalanzani, A. (2011), "Knowledge management in supply chain: an empirical study from France", The Journal of Strategic Information Systems, Vol. 20 No. 3, pp. 283-306.

Teece, D.J. (2007), "Explicating dynamic capabilities: the nature and microfoundations of (sustainable) enterprise performance", Strategic Management Journal, Vol. 28 No. 13, pp. 1319-1350.

Xue, C.T.S. (2017), "A literature review on knowledge management in organizations", Research in Business and Management, Vol. 4No No. 1, pp. 30-41.

\section{Author affiliations}

Armando Papa is based at the Faculty of Business and Economics, University of Rome Universitas Mercatorum, Rome, Italy.

Roberto Chierici is based at the Department of Business and Law, University of MilanBicocca, Milan, Italy.

Luca Vincenzo Ballestra is based at the Department of Statistical Sciences, Alma Mater Studiorum University of Bologna, Bologna, Italy.

Dirk Meissner is based at the Institute for Statistical Studies and Economics of Knowledge, National Research University Higher School of Economics, Moscow, Russian Federation.

Mehmet A. Orhan is based at the Department of Management and Strategy, Paris School of Business, Paris, France.

\section{About the authors}

Armando Papa is an Associate Professor of Management at the University of Rome Universitas Mercatorum. Priorly, he has been a Research Fellow at University of Turin. He holds a PhD in Management achieved at the University of Naples Federico II. He holds a Postgraduate Master in Finance (2011). He is also a Member of the EuroMed Research Business Institute. He won the Best Paper Award at the 9th EuroMed Conference in Warsaw (Poland) in 2016. He is skilled in KM, entrepreneurship and corporate governance and family business management. He is an Associate Editor of Journal of Knowledge Economy Springer and Managing Assistant Editor of Journal of Knowledge Management Emerald. He is engaged in various peer-review processes for several ranked and outstanding international management. He is a Board Member of the Journal of Intellectual Capital and Management Research Review. He is a Member of the I.P.E. Business School of Naples. 
Roberto Chierici is an Assistant Professor of Marketing at the Department of Business and Law of the University of Milan-Bicocca, Italy. He obtained his PhD in Business Administration, Management and Territorial Economics from the University of Milan-Bicocca in 2016. His research interests lie in the areas of social media and customer relationship management, social commerce, multichannel customer management, social media, information and KM and new forms of entrepreneurship. Roberto Chierici is the corresponding author and can be contacted at: roberto.chierici@unimib.it

Luca Vincenzo Ballestra has received a BSc in Aerospace Engineering from the Politecnico University of Milan and a PhD in Applied Mathematics from the University of Milan. From January 2016, he is an Associate Professor of Mathematics for Economics at the Rimini Campus of the University of Bologna (Department of Statistical Sciences), where he currently teaches various courses of Mathematics at the bachelor's and master's degrees focused on statistical sciences. His research interests include mathematical and statistical methods for economics and computational finance.

Dirk Meissner is a Distinguished Professor at National Research University Higher School of Economics, Moscow and Head of Laboratory Economics of Innovation and Academic Supervisor Master Programme "Governance Science, Technology and Innovation". He has 20 years of experience in research and teaching technology and innovation management and policy. He has strong background in science, technology and innovation for policymaking and industrial management with special focus on innovation management and road mapping, science, technology and innovation policies, funding of research and priority setting. Dirk is an Associate Editor for Technological Forecasting and Social Change and IEEE Transactions on Engineering Management and Editor Springer book series Science, Technology and Innovation Studies.

Mehmet A. Orhan (PhD) is an Associate Professor of Management at Paris School of Business since 2018. He is also a Faculty member at the University of Liverpool where he supervises doctoral students in management, organizational behavior and information technologies. He received his Doctoral degree from Tilburg University in the Netherlands. He also holds an MBA from DePaul University in Chicago and an MSc from the Solvay Business school of Vrije Universiteit Brussel. His research interests include organizational communication, behavioral dynamics in technology-intensive organizations and alternative work arrangements.

For instructions on how to order reprints of this article, please visit our website: www.emeraldgrouppublishing.com/licensing/reprints.htm

Or contact us for further details: permissions@emeraldinsight.com 